Mirosław Skarżyński

Uniwersytet Jagielloński, Kraków

miroslaw.skarzynski@gmail.com

\title{
ROSYJSKIE ЛИПА, ЛИПОВЫЙ I POLSKIE LIPA, LIPNY
}

Słowa klucze: etymologia, zapożyczenia, język złodziejski, język polski, język rosyjski Keywords: etymology, borrowings, thieves' language, Polish, Russian

1. W swoim słowniku etymologicznym Andrzej Bańkowski w haśle LIPA 2. „slang. warsz. 1905 'namiastka, falsyfikat [...], zwłaszcza oferowany przez oszusta jako prawdziwy" hasłowy rzeczownik objaśnia jako zapożyczenie z języka rosyjskiego, a dokładniej z jego potocznej odmiany: „z ros. pot. lipa 'namiastka', najpierw chyba o wywarze $z$ kwiatu lipowego podawanym zamiast herbaty...” (SEBań). Pomijając użycie w definicji polskiego znaczenia słowa 'namiastka', co nie ma potwierdzenia ani w polskich słownikach (SJPD, SJPSz, USJP), ani w znanych mi użyciach tego wyrazu, włączając $w$ to dane $z$ NKJP, nie uważam za prawdziwe objaśnienia pochodzenia polskiej lipy przez przywołanie rosyjskiego 'заменитель', 'эрзаи', 'суррогат', niepotwierdzonego $\mathrm{w}$ żadnym $\mathrm{z}$ dostępnych mi słowników rosyjskich (BTSRJa, SRJa, SRJaJew, BTSRJaKuz), a także w NKRJa. Znaczenie rosyjskiego wyrazu runa to (pomijając nazwę drzewa) 'фальшивка, подделка' (SRJa), 'фальшивый документ, вещь и т. п.; фальшивка’ (SRJaJew), a także: „Ирон.'Ложные, неправильные сведения (приводимые обычно сознательно с целью обмана, введения в заблуждение кого-л.)" (BTSRJaKuz). Wyjaśnienie genezy znaczenia przez odniesienie do naparu z kwiatów lipy, mającego udawać herbatę także jest wątpliwe i znaczeniowo, i faktycznie, należy więc poszukać innego.

Trzeba też od razu powiedzieć, że polski rzeczownik lipa a) 'oszustwo', b) 'coś zrobionego niesolidnie' nie ma nic wspólnego z rzeczownikiem lipa 'gatunek drzewa' - 
mamy tu nie polisemię, ale homonimię, należałoby więc w polskich słownikach hasłować je oddzielnie, a nie jako drugie znaczenie nazwy gatunku drzewa.

Na rosyjskich forach internetowych o tematyce językowej można znaleźć próby objaśnienia znaczenia 'подделка', wiążące je z procederem podrabiania pieczęci $\mathrm{w}$ drewnie lipowym lub $\mathrm{z}$ tanimi ikonami malowanymi na desce lipowej zamiast na wykonanej ze szlachetnego drewna. Żadnego z tych wariantów nie można potwierdzić w materiałach słownikowych i w literaturze, ponadto drugi jest wręcz zabawny, jeśli się wie, że rosyjskie ikony malowano przede wszystkim na deskach lipowych, a tylko tam, gdzie lipy nie rosły, np. na Syberii, używano innego drewna (sosnowego).

Wskazówką, za którą należało pójść w poszukiwaniu genezy rosyjskiej lipy, jest informacja w słowniku Dmitrija N. Uszakowa: „простореч. вульг., из воровского арго" (BTSRJa; wyróżn. M.S.), powtórzona w I-ESSRJa Pawła Ja. Czernycha z odesłaniem do słownika Władimira I. Dala (TSŻWJa).

\section{Rosyjskie липовый і липа}

W TSŻWJa w haśle-gnieździe czasownika липнyms ('przykleić się, przylgnąć) W. Dal podaje rzeczownik липок należący do żargonu szulerów. Tak nazywano specjalny klej służący do łączenia ze sobą dwóch kart w taki sposób, by w zależności od sytuacji w grze można było posłużyć się jedną lub drugą ${ }^{1}$ Rzeczownik jest derywacyjną bazą przymiotnika липковый, wchodzącego w skład także szulerskiej nazwy odnoszącej się do jeszcze innego sposobu preparowania kart: липковое очко - oczko karty przyklejone owym klejem tak, że można było je albo zakryć, albo odkryć, co zmieniało wartość punktową karty².

W odniesieniu do pierwszej połowy XIX w. można przywołać też powieść Wsiewołoda W. Kriestowskiego Pietierburgskije truszczoby (1864), która jest, podobnie jak polski utwór K.R. Rusieckiego Małe tajemnice Warszawy. Zarysy obyczajowe oryginalne (1844, zob. Ułaszyn 1913/2009, 1951), potomkiem Tajemnic Paryża Eugeniusza Sue. Obie książki, rosyjską i polską, łączy także wprowadzenie dla celów stylizacji wyrazów pochodzących z języków złodziejskich (odpowiednio polskiego i rosyjskiego, zob. Ułaszyn 1951; Smirnow 1899). U Kriestowskiego znajdujemy nazwę podrobionego paszportu липовой глазок (< глаз ros.-złodz. 'paszport'), со pozwala przyjąć, że w tym samym czasie, kiedy w żargonie szulerów funkcjonował

1 „Липокъ или липецъ [...] липки [мн.] [...] въ шулерск. картежн[ой] игрь, липокъ, мазь, липкая, но не маркая, которую спаиваются двђ карты и даютъ средство ставщику вскрыть любую” (TSŻWJa).

2 „Липковое очко, етою жь мазю наклеенное очко, которое легко отстаетъ, если шаркнуть картою, и шулеръ вскрываетъ, по надобности, двоїку либо троїку, четверку либо пятерку..." (TSŻWJa). Opis podobnie spreparowanej karty - waleta/króla - można znaleźć we wspomnieniach naczelnika rosyjskiej policji śledczej (Koszko 1926-1927). 
przymiotnik липковыц̆, w żargonie złodziejskim był липовый 'fałszywy, podrobiony’. Natomiast nie udało się znaleźć poświadczenia istnienia w tamtym czasie rzeczownika runa w znaczeniu tu nas obchodzącym. Podaje go dopiero słownik słynnego w swoim czasie aferzysty Wasilija F. Trachtienbierga (1908), do którego materiały zebrał on w czasie pobytu w moskiewskim więzieniu na Tagance, a który został zredagowany i wydany przez Jana Baudouina de Courtenay: „Липа. Всякий фальшивый, поддельный документ". Татże znajdujemy липовые очки 'поддельный паспорт'. O cztery lata późniejszy słowniczek kijowskiego pristawa policji W.M. Popowa (1912) notuje липовые очки 'поддельный паспорт', a także липовая сарга 'фальшивые деньги'.

Powstaje pytanie o to, w jakim stosunku pozostają do siebie przymiotniki липковыц (<липок) і липовый. Można tu tylko stawiać hipotezy, których co prawda nie sposób zweryfikować z oczywistego powodu, jakim jest brak danych bezpośrednich. Przyjmijmy więc taką.

Липковое очко podległo leksykalizacji od znaczenia 'oczko naklejone' do 'oczko fałszywe', a sam przymiotnik липковый zyskał znaczenie 'fałszywy, podrobiony'. To przypuszczenie mogłoby zostać wzmocnione istnieniem nazwy ^липковая карта, na co, niestety, żadnych poświadczeń nie ma. Idąc dalej, przyjmijmy, że usamodzielniony przymiotnik липковый został zapożyczony do języka złodziejskiego, tam zaś jako wyraz „obcy” i pozbawiony bazy derywacyjnej (desygnat rzeczownika липок nie miał zastosowania w "pracy” złodziei, a więc i sam wyraz był zbędny) został zasocjowany z bliskim brzmieniowo i dobrze znanym липовыц (< липа 'drzewo'). Tę postać znajdujemy w najwcześniejszym ze znanych zapisów - липовый глазок 'fałszywy paszport' u Kriestowskiego. W błatnej muzyce utrwalił się wariant липовые очки, przy czym, o ile wiem, nieznana jest geneza znaczenia 'paszport, dokument' rzeczowników очки (plurale tantum) і глаз 'ts.'. Późniejsze rozszerzenie łączliwości przymiotnika na inne rzeczowniki nie wymaga specjalnego tłumaczenia.

Wczesnodwudziestowieczne poświadczenia przymiotnika липовый 'fałszywy, podrobiony’ znaleźć można w książce „króla rosyjskiego dziennikarstwa”, Własa M. Doroszewicza, Sachalin (1903), dalej u Walentina W. Kuricyna (Tomskije truszczoby, 1906), a także w słowniczkach języka złodziejskiego (Potapow 1927; Tonkow 1930) ${ }^{4}$. Ten drugi informuje o używaniu przymiotnika липовый już także w języku

3 Deminutivum глазок u Kriestowskiego nie jest formą podstawową. Zob. „Глазъ ‘паспортъ, метрическое свидьтельство или какой другой документ, по которому можно было бы прописаться” (Trachtienbierg 1908), także „Глаз темный 'паспорт поддеьный', Глаз яманный” 'ts.' (Popow 1912).

4 „Липа - чужой или поддельный документ”. „Липовая сарга - фальшивые деньги”. „Липовые очки - фальшивый паспорт” (Potapow 1927). „Прилагательное липовый [...] активно в современной русской разговорной речи, ср. липовый паспорт, диплом, удостоверение, липовые документы, липовая справка" (Tonkow 1930). Notabene oba te słowniki czerpią materiał z Popowa, a pośrednio też z Trachtienbierga (zob. Płucer-Sarno on-line). 
potocznym. W obieg pisany (prasa) wyraz wszedł w latach 20. XX w. wraz z wieloma innymi podobnej proweniencji, które po roku 1917 proletaryzowały i lumpenproletaryzowały literacki język rosyjski (Sieliszczew 1928). Po raz pierwszy w słowniku standardowego języka rosyjskiego типовый został odnotowany przez D. Uszakowa (BTSRJa) jako gwarowy (gwara miejska) i wulgarny.

Rosyjski rzeczownik типа 'всякий фальшивый, поддельный документ' (Trachtienbierg 1908), potem zaś także w ogóle 'każda rzecz podrobiona' ‘фальшивый документ, вещь и т. п.; фальшивка' (SRJaJew ), wreszcie także 'ложные, неправильные сведения' (BTSRJaKuz) trzeba, jak się wydaje, uznać za produkt paradygmatycznej (z ucięciem) derywacji uniwerbizacyjnej od przymiotnika липовыı̆:

липовые очки, липовая сарга, что-то липовое $\rightarrow$ липа 'фальшивка'

Nie da się oczywiście ustalić, kiedy owa derywacja zaszła, w każdym razie w ostatnich dziesięcioleciach XIX w. rzeczownik ten już istniał, być może także poza językiem złodziejskim - w niskich rejestrach języka potocznego.

Podsumowując, historię rosyjskiego przymiotnika липовый można przedstawić następująco:

1. żargon szulerski $>2$ 2. żargon złodziejski $>$ 3. ros. gwary miejskie $>$ 4. ros. j. potoczny

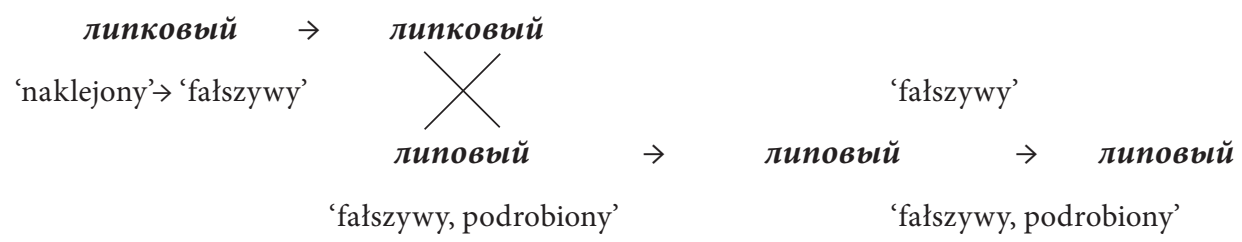

\section{Polskie lipa i lipny}

Inaczej niż to pokazano w odniesieniu do języka rosyjskiego, w wypadku polszczyzny pierwszy, jak można przyjąć, był zapożyczony rosyjski żargonowy rzeczownik lipa, przymiotnik zaś lipny jest późniejszy (SEBań) i jest derywatem. Interesującego nas znaczenia nowej lipy 'fałszywka, podróbka' nie notują słowniki XIX w. (SL, SWil) ani SW. Uwzględnia je dopiero SJPD z kwalifikatorem „wiechowy” (= gwara miejska warszawska), w dwóch znaczeniach, ujętych przez autorów SJPD w jednej definicji, co potem powtórzył SJPSz:

lipa 2. wiech. oszustwo, kłamstwo, bujda; także o czymś niesolidnym, źle zrobionym itp. (SJPD),

lipa 2. blm pot. «oszustwo, kłamstwo, bujda; także o czymś niesolidnym, źle zrobionym; tandeta» (SJPSz). 
Dopiero w USJP PWN oba znaczenia zostały rozdzielone:

lipa a) «oszustwo, kłamstwo, nieprawda», [...] b) «coś marnego, niesolidnego, niskiej jakości; tandeta».

Jako wyraz obecny w warszawskiej gwarze uczniowskiej podaje lipe Bronisław Wieczorkiewicz:

Lipa 2. gw. szk. bzdura, rzecz nieprawdziwa (SGW),

wskazując źródło, którym był niepublikowany słownik Antoniego Opęchowskiego, zawierający słownictwo uczniów warszawskich z lat 1915-1935. Wydaje się, że do tego substandardu wyraz przeszedł nie wcześniej niż w drugim dziesiątku lat wieku XX, zapewne z warszawskiej gwary miejskiej ${ }^{6}$.

Obecność lipy i lipnego w warszawskim wiechu nasuwa pytanie o ich źródło. Można, jak sądzę, wykluczyć potoczny rosyjski, ponieważ ta warstwa ludności, która w grę wchodzi, na ogół nie miała codziennej styczności z rosyjskim ani w odmianie kulturalnej, ani potocznej, nie mówiąc już o rosyjskich gwarach miejskich. Jako medium przyjąć wypada tu polski język złodziejski, ponieważ jakaś część jego użytkowników miała mniej lub bardziej ożywione kontakty ze złodziejami rosyjskimi, nie tylko zawodowe, ale też często więzienne, za czym przemawia obecność pewnej liczby zapożyczeń polskich w błatnej muzyce i rosyjskich w polskim języku złodziejskim - w jego „dialekcie królewieckim”, bo o „galicyjskim” mówić z oczywistych powodów nie można. Tak więc brak lipy w słowniku Karola Estreichera (1903) czy Antoniego Kurki (1907) nie dziwi. Natomiast niepokoi nieco brak lipy u Henryka Ułaszyna (1951), choć i to da się wyjaśnić okolicznościami powstania jego książki i losami jego zbiorów słownikowych?

Pozostaje sięgnąć do daleko powojennego słownika Klemensa Stępniaka (STGP), który mimo marnego poziomu leksykograficznego dostarcza obszernego materiału, także z dawniejszych zbiorów leksyki przestępczej. Trzeba się jednak zastrzec, że wobec braku wstępu podającego zasady opracowania materiału, w tym zasadę hierarchizacji znaczeń w hasłach, korzystanie z STGP jest dość ryzykowne.

\section{LIPA}

1. rzeczy kradzione małej wartości

2. złodziej kradnący rzeczy małej wartości

5 Słownik gwary uczniowskiej. Słowa, zwroty, powszednie wyrażenia, wymysty i ogólne przezwiska używane $w$ mowie szkolnej $w$ Warszawie $w$ ostatnim dwudziestoleciu. Zebrał, objaśnił i wstępem opatrzył Antoni Opęchowski, Warszawa 1935. Maszynopis był w posiadaniu B. Wieczorkiewicza.

6 Nie ma go w każdym razie w materiałach języka uczniowskiego obejmujących słownictwo $\mathrm{z}$ lat 1883-1906, a z Królestwa Polskiego, w tym z Warszawy, do roku 1912. Zob. (Ułaszyn 1938/2009).

7 Jak pisze Ułaszyn w Przedmowie do Języka złodziejskiego „Z obszernej zaś pracy naukowej o języku złodziejskim ocalało tylko kilkadziesiąt kartek; obszerny słownik złodziejsko-polski, zawierający około 3000 pozycji (na fiszkach), przepadł całkowicie [w 1939 r. w Poznaniu M.S.]” (Ułaszyn 1951: 10). 


\section{3. oszustwo, kłamstwo \\ 4. fałszywy dokument \\ 5. fałszywe nazwisko \\ 6. lipy fałszywe pieniądze \\ [wyróżn. M.S.]}

Znaczenie 4. jest zbieżne z rosyjskim 'всякий фальшивый, подделный документ' (Trachtienbierg 1908), wobec czego przyjmiemy je jako punkt wyjścia. Dalsze jego umiejscowienie w haśle STGP może świadczyć o dawności i być może peryferyjności znaczenia w czasie, gdy Stępniak pisał swój słownik. Nie daje jednak informacji o tym, kiedy rzeczownik lipa trafił do języka polskich złodziei. Pozostaje więc tylko pośrednie wnioskowanie na podstawie datacji w SEBań - $1905 \mathrm{r}$. Data ta informuje o pierwszym (?) użyciu lipy w tekście drukowanym (SEBań I: XXIII). Bańkowski kwalifikuje wyraz należący do gwary warszawskiej (slang. warsz.), ale - co nie jest dla nas bez znaczenia - objaśnia go: „falsyfikat, towar podrobiony, zwłaszcza oferowany przez oszusta jako prawdziwy", co może świadczyć o tym, że albo w gwarze warszawskiej nastąpiła generalizacja pierwotnego znaczenia 'fałszywy dokument', albo że dokonała się ona już w polskim języku złodziejskim. W STGP brak owego uogólnionego znaczenia, które podaje Bańkowski, można jednak sądzić, że generalizacja mogła nastąpić $\mathrm{w}$ szeroko rozumianym środowisku marginesu społecznego, bez wchodzenia w szczegółowe podziały na złodziei, oszustów zawodowych itp. Natomiast trzeba przyjąć, że skoro w roku 1905 lipa pojawiła się w tekście pisanym (prasowym?), to musiała dość długo już funkcjonować poza językiem „tajnym”. Można więc uznać, że zapożyczenie rosyjskiej lipy nastąpiło - najogólniej - w drugiej połowie wieku XIX, ale nie sposób zaproponować ściślej określonego przedziału czasowego.

Drogę lipy na polskim gruncie można przedstawić następująco:

j. złodziejski $\rightarrow$ gwara miejska warszawska $\rightarrow$ potoczny język polski

Druga rzecz to stosunek między znaczeniami w STGP. Podstawowym, odpowiadającym rosyjskiemu pierwowzorowi jest tu znaczenie 4. 'fałszywy dokument', od którego nastąpiła zapewne derywacja semantyczna znaczenia 5. 'fałszywe nazwisko'. Derywacja paradygmatyczna od 4. dała lipy (plurale tantum) 'fałszywe pieniądze'.

Pewne wątpliwości nasuwa w STGP znaczenie 3. 'oszustwo, kłamstwo' wobec informacji Bańkowskiego o rozwoju w latach okupacji niemieckiej znaczenia warszawskiej gwarowej lipy od 'falsyfikat' do 'oszustwo, kłamstwo, blaga' w polszczyźnie, jak trzeba rozumieć, potocznej, w której funkcjonuje do dzisiaj. Znów nie da się rozstrzygnąć, czy to znaczenie jest innowacją w języku potocznym, czy też przejęciem z gwary warszawskiej pożyczki z języka marginesu. Nie rozstrzygając więc niczego, podajmy tylko ogólną ścieżkę rozwojową znaczenia: 
'fałszywy dokument' $\rightarrow$ 'każdy podrobiony przedmiot służący oszustwu' $\rightarrow$ oszustwo (czynem) $\rightarrow$ oszustwo werbalne (= kłamstwo),

(1) W szufladzie mam dwa dokumenty, komplety papierów - Jerzy potyka się o myśl, zdenerwowany, nie może sobie przypomnieć, czy w portfelu są prawdziwe, te, o które teraz chodzi, czy lipa [= fałszywka] (NKJP).

(2) Ten papier $\mathrm{z}$ podpisem generała to też lipa [= nieprawdziwy]?

(3) Że cały ten proces to lipa! [= fikcja, czynność fikcyjna] Przecież macie już na nas wyrok, no więc? (NKJP).

(4) Lipa [= nieprawda], Zawadzkiego nie było w Moskwie i do nas przyjeżdżał bardzo rzadko (NKJP).

Podobny, acz nieidentyczny rozwój znaczenia można zaobserwować dla pierwowzoru rosyjskiego, por.

'всякий фальшивый, поддельный документ' > 'фальшивка, подделка' (przedmiot służący oszustwu) $\rightarrow$ 'ложные, неправильные сведения (приводимые обычно сознательно с целью обмана...' (nieprawdziwe słowa, kłamstwo/oszustwo werbalne).

(5) Выгода здесь обоюдная - в предприятие «высокой культуры быта» не зарастает народная тропа, а приезжий, собственноручно заплатив в гостиничную кассу 1500 рублей за три месяца, может быть уверен, что его документы не «липа» [= fałszywka] (NKRJa).

(6) Либо этот «план» — грубейшая «липа» [= fikcja] (настоящие «профи» ТАК не пишут), либо - мои худшие подозрения об уровне и стиле отдельных московских пиарщиков подтверждаются лишний раз... (NKRJa).

(7) Ну ребята, я сразу догадался, что ето липа [= kłamstwo], ето скорее речь какого-то провокатора (NKRJa).

Pozostaje do omówienia przymiotnik od polskiej lipy. Stępniak notuje przymiotnik lipny tylko jako składnik określenia lipny czek 'kradzież z kasy'. Nie można jednak wyciągać $\mathrm{z}$ tego wniosku o nieużywaniu tego przymiotnika ${ }^{8} \mathrm{w}$ połączeniu $\mathrm{z}$ innymi rzeczownikami, także wobec hasła w tymże słowniku lipniarz 'oszust', którego struktura wskazuje na podstawę lipn-, a znaczenie można uznać za związane pośrednio z rzeczownikiem lipa 3. Por. 3. 'oszustwo, kłamstwo' $\rightarrow$ *lipny 'odnoszący się do lipa 3 ' $\rightarrow$ lipniarz. Natomiast brak lipnego w SGW. Notuje go SJPD z kwalifikatorem

8 Byłoby doprawdy dziwne, gdyby ten przymiotnik został derywowany tylko po to, by mógł zostać użyty w połączeniu z rzeczownikiem czek. To raczej jeszcze jeden przypadek pokazujący „fachowość" warsztatu autora STGP. 
wiechowy z objaśnieniem 'nieprawdziwy, fałszywy, oszukańczy' oraz w tym samym ciągu definicyjnym: 'zrobiony nie tak, jak należy, jak trzeba'. Są tu więc złączone dwa odrębne znaczenia. To drugie jest o tyle interesujące, że synonimiczne do 'lichy, tandetny' (co dodaje SJPSz) i dobrze motywowałoby lipe 1., 2. w STGP: 1. 'rzeczy kradzione małej wartości', 2. 'złodziej kradnący rzeczy małej wartości', a więc lipa 1. mogłaby być derywatem (paradygmat + ucięcie) od owego znaczenia przymiotnika lipny, a lipa 2. derywatem semantycznym od lipa 1. Sam przymiotnik przyjął się w polszczyźnie potocznej, por.

(8) kościół - lipny [= fałszywy] gotyk, ale z daleka fajny (NKJP).

(9) Wuj adwokat załatwił mi lipny [= pozornie rzeczywisty] etat w firmie Niemca, który przychodził do niego po porady prawne (NKJP).

(10) Film był nudny, lipny [= byle jaki, tandetny] i przewidywalny jak sprawa Rywina (NKJP).

W STGP znajdujemy też hasło lipowy 'sfałszowany' z powołaniem się na tom reportaży Aleksandra Matogi-Ferensa Twarze $z$ dna z 1936 r. Jest to ślad, być może wskazujący na zarzucone ostatecznie użycie tego przymiotnika w znaczeniu związanym ze znaczeniem rzeczownika lipa 'oszustwo'. Drugim tego rodzaju śladem jest hasło lipowo w Słowniku gwary więziennej (Michalski, Morawski 1971). Jest to przysłówek, wyraźnie odprzymiotnikowy, o znaczeniu 'źle, niedobrze', który wskazywałby na istnienie przymiotnika lipowy w znaczeniu 'zły, niewłaściwy', choć nie sposób już odtworzyć jego powiązania ze złodziejską lipą.

Obie pary wyrazów, rosyjska i polska, przeszły tę samą drogę w językach, do których należą, awansując z peryferycznych odmian do potocznej odmiany języka ogólnego. Rozwój znaczeń, jakiemu podległy, okazuje się też podobny. Należy postawić pytanie o słuszność hipotezy dotyczącej etymologii rosyjskiej pary wyrazów. Pozostanie ona nadal hipotezą, ponieważ jej weryfikacja wobec braku bezpośrednich poświadczeń nie jest możliwa. Co najwyżej można powiedzieć, że jest lepsza od wiązania 'подделки' z naparem z kwiatu lipy. 


\section{Literatura}

BTSRJA: Д.М. Ушаков, Большой толковый словарь современного русского языка, Москва 1935-1940.

BTSRJaKuz: Большой толковый словарь русского языка. Гл. ред. С.А. Кузнецов, Санкт Петербург 1998/2009, on-line: gramota.ru/slovari/dic/.

Doroszewicz W.M., 1903, = B.M. Дорошевич, Сахалин. Каторга. Южно-Сахалинск 2005.

Estreicher K., 1903, Szwargot więzienny. Zestawił..., Kraków.

I-ESSRJA: П.Я. Черных, Историко-етимологический словарь современного русского языка, т. 1, Москва 1993/¹999.

Коszко A.F., 1926-1927, = А.Ф. Кошко, Среди убийи и грабителей. Воспоминания бывшего начальника московской сыскной полииии, Paryż.

Kriestowski W., 1864, = В.В. Крестовский, Петербургские трущ,обы, Москва 2011.

Kuricyn W., 1906, = В.В. Курицын, Томские трущзобы, Москва 2012.

Kurka A., 1907, Słownik mowy złodziejskiej, Lwów.

Michalski H., Morawski J., 1971, Słownik gwary więziennej, Departament Szkolenia i Wydawnictw MSW, [Warszawa] 1971.

NKJP: Narodowy Korpus Języka Polskiego, on-line: http://nkjp.pl/, dostęp 10 IX 2014.

NKRJA: Национальный корпус русского языка, on-line: www.ruscorpora.ru/. dostęp 10 IX 2014.

PŁUCER-Sarno on-Line: A.Ю.Плуцер-Сарно, История словарей русского воровского арго. Часть 1. Как воровать воровские слова, on-line: plutser.ru/histogy_dictionary/ hargo/document.2005-04-06.3617147496, dostęp 12 IX 2014.

Popow W.M., 1912, = В.М. Попов, Словарь воровского и арестантского языка. Посвящзаю всем товарищам-сослуживиам, чинам наружной и сыскной полииии российской Империи. Пристав В. Попов, Киев 1912.

Ротаро木 S.M., = С.М. Потапов, Словарь жаргона преступников (блатная музика). Составил по новейшым данным..., НКВД 1927.

SEBAŃ: A. Bańkowski, Etymologiczny słownik języka polskiego, Warszawa 2000.

SGW: B. Wieczorkiewicz, Słownik gwary warszawskiej, Warszawa 1986.

Sieliszczew A.M., 1928, = A.M. Селищев, Язык революицонной епохи. Из наблюдений над русским языком (1917-1926), Москва.

SJPD: W. Doroszewski (red.), Słownik języka polskiego, Warszawa 1958-1969.

SJPSz: M. Szymczak (red.), Słownik języka polskiego, Warszawa 1978-1981.

SL: S.B. Linde, Stownik języka polskiego, Warszawa 1807-1815.

Smirnow N.A., 1899, = Н.А. Смирнов, Слова и выражения воровского языка, выбранные из романа Вс. Крестовского "Петербургские трущ,бы», „Известия Отделения русского языка и словесности Императорской Академии наук”, T. IV. Кн. 3., S. $1065-1087$.

SRJA 1949: С.И. Ожегов, Словарь русского языка, Москва.

SRJaJew: А.П. Евгеньевой (red.), Словарь русского языка. В 4-х m. Москва 1999, on-line: http://feb-web.ru/feb/mas/mas-abc/default.asp.

STGP: K. Stępniak, Słownik tajemnych gwar przestępczych, Londyn 1993. 
SW: J. Karłowicz, A. A. Kryński, W. Niedźwiedzki (red.), Słownik języka polskiego, Warszawa 1900-1927.

SWIL: A. Zdanowicz i in., Słownik języka polskiego, t. I-II, Wilno 1861.

Tonkow W., 1930, = В. Тонков, Опыт исследования воровского языка, Казань.

Trachtienbierg W.F., 1908, = В.Ф. Трахтенбергъ, Блатная музыка (Жаргонъ тюрьмы), По матеріаламъ, собраннымъ въ пересильныхъ тюрьмахъ: Петербургской, Московской („Бутырки”), Виленской, Варшавской, Кіевской и Одесской; въ тюрьмахъ: въ „Крестахъ”, въ „ДомБ предварительного заключенія”, въ „Дерябинскихъ казармахъ” (Петербургъ), въ „Каменщикахъ” (Москва). Подъ редакціей и съ предисловіемъ профессора И.А. Бодуэнъ-де-Куртенэ, С-Петербургъ.

TSŻWJA: В. Даль, Толковый словарь живого великорусского языка, Санкт Петербург $1861-1868 /{ }^{2} 1880-1884$.

UŁASZyn H., 1913/2009, Przyczynki leksykalne 1. Gwara złodziejska z około roku 1840, „Materiały i Prace Komisji Językowej Akademii Umiejętności w Krakowie” t. VI. Przedr. w: idem, Studia onomastyczne i socjolingwistyczne. Wstęp i dobór tekstów M. Skarżyński i B. Walczak, „Klasycy Nauki Poznańskiej” t. 41, Poznań, s. 46-61.

UŁaszyn H., 1938/2009, Przyczynki leksykalne 2. Trzy gwary uczniowskie: Wielkopolska, Królewiacka i Galicyjska, (w:) idem, Studia onomastyczne..., s. 62-114.

UŁASZYN H., 1951, Język złodziejski. La langue des voleurs, Łódź.

USJP: S. Dubisz (red.), Uniwersalny słownik języka polskiego, t. 1-4, Warszawa 2003.

\section{Russian лuna, липовый 'counterfeit' and Polish lipa, lipny 'false' Summary}

The paper debates the interpretation of the etymology of Polish lipa 'something untrue' given by A. Bańkowski in his Etymologiczny słownik języka polskiego 'Etymological dictionary of Polish'. Based on Russian and Polish lexicographical data, the author describes the rise of the Russian noun runa as a derivative from the older adjective типовы $\breve{u}$ 'false, counterfeit' in the thieves' slang of the $19^{\text {th }}$ century, and subsequently its path into colloquial Russian. The word lipa was borrowed into Polish in the second half of the $19^{\text {th }}$ century in the meaning 'fake passport, document', also 'something counterfeit'. It first appeared in the slang of Polish thieves, then penetrated into the dialect of Warsaw, and eventually into colloquial Polish where it is used as a polysemous word, and became the base for the also polysemous derivative adjective lipny. 